\title{
ROWELL SYNDROME - A CONTROVERSIAL CLINICAL ENTITY
}

\author{
Iulia-Tania Andronache ${ }^{1,2}$, Cristina Suta ${ }^{1,2}$, Claudiu Ionescu ${ }^{1}$, Anca Calistrat ${ }^{1}$, Maria Suta ${ }^{1,2}$ \\ ${ }^{1}$ Rheumatology Department, IInd Internal Medicine Clinic, \\ Sf. Apostol Andrei Emergency Clinical County Hospital, Constanta \\ ${ }^{2} 3 r d$ Department, Ist Clinical Disciplines, Faculty of Medicine, Ovidius University, Constanta
}

\section{BACKGROUND}

Rowell syndrome is defined by the association between systemic lupus erythematous (SLE), erythema multiforme (EM) and characteristic immunological findings. Ever since 1963, when the condition was described by Rowell (1), there have been discussions in the literature whether this syndrome is a stand-alone clinical entity or a mere coincidence.

The diagnosis criteria established by Zeitouni et al. in 2000 may be divided in major criteria (SLE, discoid lupus erythematosus or subacute lupus erythematosus, erythema multiforme like lesions, with or without mucous involvement and positive antinuclear antibodies - ANA - with a speckled immunofluorescence pattern) and minor criteria (chilblains or pernio, positive antiRo or antiLa antibodies and a positive rheumatoid factor). In order to establish positive diagnosis all the major criteria and at least one minor criteria need to be fulfilled (2).

We present the case of a patient with late-onset systemic lupus erythematosus, with speckled ANA immunofluorescence pattern and a positive rheumatoid factor (RF), who developed an EM-like rash.

\section{CASE PRESENTATION}

An 81-year old woman with one year history of late-onset systemic lupus erythematosus with systemic (fever, anorexia, weight loss), musculoskeletal (myalgia, polyarthritis), cutaneous (photosensitivity), hematological (leukopenia and lymphopenia) and immunological manifestations (ANA intensely positive with a speckled pattern, positive anti dsDNA antibodies and a positive rheumatoid factor) presents for painful and pruritic erythematous plaques over her thighs, chest and back. The patient has interrupted her treatment regimen with Hydroxycloroquine (complains of malaise) and continued her 5 milligrams a day corticosteroid treatment. She also has a history of osteoporosis with vertebral fractures (biphosphonate treatment for the past three years).

Physical examination at the moment of the admission showed multiple annular erythematous squamous plaques with vesicular borders and central erosions over her thighs, chest (Figures 1 and 2), arms and back. She also complained of polyarthralgia in her interphalangeal and metacarpophalangeal joints, but without peripheral arthritis.

Correspondence address:

Iulia-Tania Andronache, Rheumatology Department, Ind Internal Medicine Clinic, Sf. Apostol Andrei Emergency Clinical County

Hospital Constanta, 145 Tomis Blvd, 900591, Constanta, Romania

E-mail: andronacheiulia@gmail.com 


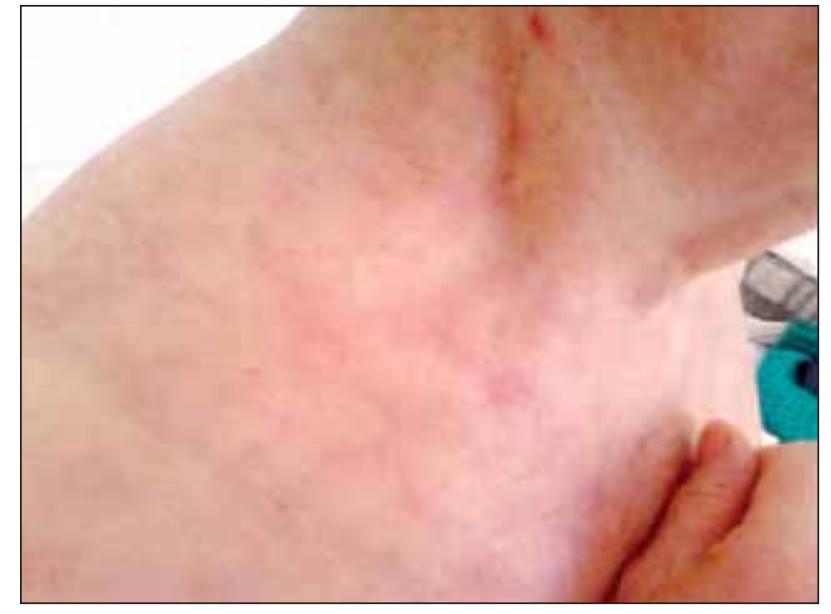

FIGURE 1. Latero-cervical erythema multiforme lesions

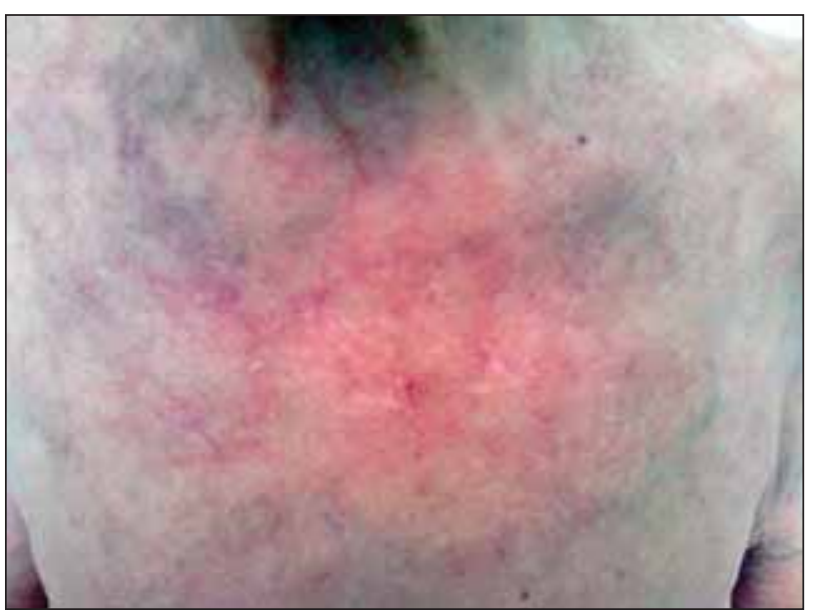

FIGURE 2. EM lesions on chest (multiple annular erythematous squamous plaques)

Laboratory tests revealed an erythrocyte sedimentation rate of $56 \mathrm{~mm} / \mathrm{h}, \mathrm{C}$ reactive protein of $2.74 \mathrm{mg} / \mathrm{dl}$, leukopenia $(3.410 / \mu \mathrm{l})$ with lymphopenia $(400 / \mu \mathrm{l})$ and a mild anemia $(11.2 \mathrm{~g} / \mathrm{dl})$. The antinuclear antibodies were intensely positive $(1 / 3,200)$ with a speckled immunofluorescence pattern and the tests for anti-Ro, anti-La antibodies were negative. The liver function tests, kidney function tests and serum complement were within normal values.

Skin biopsy taken from a lesion on the back showed slight atrophy, with marked keratinocyte necrosis, hyperkeratosis, parakeratosis and vacuolar basal changes. In the superficial dermis there was edema with inflammatory perivascular, perianexial and interstitial lymphocytic and plasmocytic infiltrate, extending towards the epidermis interpreted by the pathologists as compatible with erythema multiforme (Figure 3).

Based on the patient's pathological history (SLE), clinical manifestations at admission (erythe-

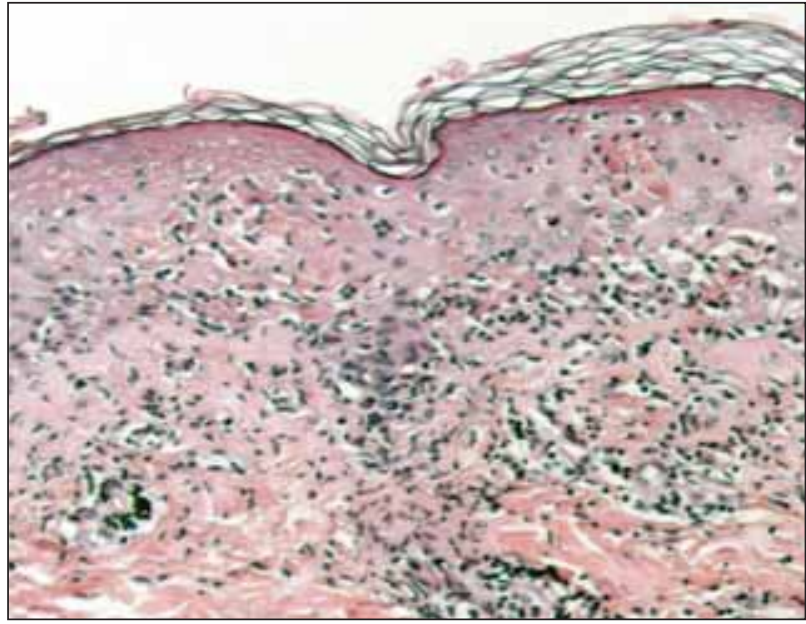

FIGURE 3. Skin biopsy, $H$-E coloration 40x, lymfocytic perivascular infiltrate, vacuolar basal degeneration and keratinocyte necrosis

ma multiforme-like rash), laboratory tests performed (antinuclear antibodies intensely positive $(1 / 3,200)$ with a speckled immunofluorescence pattern, a history of positive RF (3) and the histopathological examination, the diagnosis of Rowell's syndrome has been established. Therapy was started with Hydroxycloroquine $400 \mathrm{mg}$ /day and Prednisone $30 \mathrm{mg}$ / day (with subsequent decrease of corticosteroid doses due to osteoporosis) with partial resolution of the symptoms.

\section{DISCUSSIONS}

The first reports regarding the association between discoid lupus erythematosus (SLE) and erythema multiforme (EM) were made in 1922 by Scholtz. Later on, in 1963, Rowell et al. defined a syndrome consisting in discoid lupus erythematosus, erythema multiforme-like rash and immunological abnormalities such as positive RF, an ANA immunofluorescence speckled pattern and anti $\mathrm{SjT}$ antibodies (later identified as anti Ro/SSA and anti La/SSB). All four patients identified by Rowell et al. as having this condition were women, with discoid lupus, speckled immunofluorescence pattern, positive Rheumatoid Factor, anti $\mathrm{SjT}$ antibodies and pernio. Since Rowell established these criteria, there were multiple reports) of this so called Rowell's syndrome (71 patients) (3) and many of them did not fulfill all the clinical an serological features. 
TABLE 1. Rowell syndrome diagnosis criteria according to various authors (Rowell et al, Lee at al, Zeitouni et al)

\begin{tabular}{|c|c|c|c|}
\hline \multirow{4}{*}{$\begin{array}{l}\text { Rowell criteria (1) } \\
\text { Lupus erythematosus }\end{array}$} & \multirow{4}{*}{$\begin{array}{l}\text { Lee et al criteria (5) } \\
\text { Lupus erythematosus }\end{array}$} & \multicolumn{2}{|r|}{ Zeitouni et al criteria (2) } \\
\hline & & \multirow[t]{3}{*}{ Major } & $\begin{array}{l}\text { Lupus erythematosus (LE): systemic LE, } \\
\text { discoid LE or subacute cutaneous LE }\end{array}$ \\
\hline & & & $\begin{array}{l}\text { Erythema multiforme-like lesions (with/ } \\
\text { without involvement of the mucous } \\
\text { membranes) }\end{array}$ \\
\hline & & & (Speckled pattern of antinuclear antibody \\
\hline \multirow{3}{*}{$\begin{array}{l}\text { Erythema multiforme-like lesions (with } \\
\text { absence of any known } \\
\text { precipitating factors) }\end{array}$} & \multirow{3}{*}{$\begin{array}{l}\text { Erythema multiforme-like lesions (with } \\
\text { absence of any known } \\
\text { precipitating factors) } \\
\text { Chillblains }\end{array}$} & \multirow{3}{*}{ Minor } & Chilblains \\
\hline & & & Anti-Ro antibody or anti-La antibody \\
\hline & & & Positive rheumatoid factor \\
\hline \multirow[t]{2}{*}{$\begin{array}{l}\text { Immunological abnormalities in the } \\
\text { serum: } \\
\text { - Speckled pattern of antinuclear } \\
\text { antibody } \\
\text { - Anti-La (SS-B) antibody } \\
\text { - Positive rheumatoid factor }\end{array}$} & $\begin{array}{l}\text { Immunological abnormalities in the } \\
\text { serum: } \\
\text { - Speckled pattern of antinuclear } \\
\text { antibody } \\
\text { - Anti-La (SS-B) antibody } \\
\text { - Positive Arheumatoid factor }\end{array}$ & & \\
\hline & & \multicolumn{2}{|c|}{$\begin{array}{l}\text { Proposed diagnostic criteria for Rowell's syndrome. } \\
\text { All three major and at least one minor criteria are } \\
\text { required. }\end{array}$} \\
\hline
\end{tabular}

More recent attempts to classify this condition were made by Lee et al in 1995, suggesting the inclusion of chilblains (pernio) to the diagnostic criteria, and in 2000 Zeitouni et al defined major and minor criteria in order to offer a more consistent approach to the diagnosis (2) (Table 1). However, this expansion of criteria made the syndrome less specific.

The concept of Rowell syndrome has become lately rather controversial, some considering that the association of SLE and EM is a mere coincidence or that the cases reported were rather misdiagnosed cases of subacute SLE (3-6). Indeed, it may be challenging to clinically differentiate between annular and polycyclic lesions of subacute cutaneous LE and EM (5). Other authors have suggested that Rowell syndrome might be either a variant of cutaneous lupus erythematosus, a subtype of chronic lupus erythematosus or an independent LE subtype (3,7-12).

A modified version of Gilliam's classification of LE-non-specific skin disease includes erythema multiforme. (13,14). However, a 2012 multicenter database analysis from the European Society of CLE (EUSCLE) found that the nonspecific lesions including erythema multiforme (EM) lesions were represented by less than $2 \%$ (15).

The absence of an obvious precipitating factor for EM, be it infections, drugs, neoplasia or inflammatory bowel disease $(2,4,6,10)$, which could have complicated the picture and the presence of immunological abnormalities made us classify our pa- tient's condition as Rowell syndrome. So far, multiple case reports describing Rowell's syndrome fulfill current diagnostic criteria proposed by Zeitouni (3,7-9). Our patient presented here does not fit all the current criteria for a diagnosis of Rowell's syndrome, respectively the presence of anti-Ro antibodies and chilblains. However, the histopathological examination of the skin biopsy was consistent with EM, excluding the possibility that these were merely a cutaneous manifestation of lupus. The differential diagnosis is based on clinical appearances, histopathology and serologic findings (16) (Table 2).

The case's particularity consists in the late onset of the SLE and the absence of other cutaneous manifestations. According to the literature, cutaneous manifestations are very common in SLE patients (over $80 \%$ display skin symptoms sometime during the course of the disease and in $20-25 \%$ of patients cutaneous manifestations are the first symptom of SLE disease) (17). An important problem in a case of late onset SLE is corticoid therapy in association with osteoporosis and osteoporotic fractures.

The treatment regimens reported in the literature consisted in corticosteroids and immunosuppression with azathioprine or antimalarial drugs (mainly hydroxycloroquine) either standalone or in combination (7-9). Other authors also mention cyclosporine as a therapeutic option (18). The response to treatment is variable and frequent recurrences were reported. In spite of the rather large doses of oral steroids, our patient's lesions were relatively resistant 
TABLE 2. Clinical and histologic findings of bullous SLE, EM, Rowell syndrome and SCLE

\begin{tabular}{|c|c|c|c|c|}
\hline & Bullous SLE & EM & Rowell syndrome & SCLE \\
\hline Epidemiology & $\begin{array}{l}12-14 \text { years of age; } \\
F>M\end{array}$ & $\begin{array}{l}\text { Young adults; } 20-40 \\
\text { years of age; } M>F\end{array}$ & $\begin{array}{l}\text { Females; } 31-72 \text { years of } \\
\text { age }\end{array}$ & Young middle-aged women \\
\hline Distribution & $\begin{array}{l}\text { Face, neck, upper } \\
\text { trunk, shoulders, hands } \\
\text { (primarily } \\
\text { in sun-exposed areas) }\end{array}$ & $\begin{array}{l}\text { Dorsal hands, palms, } \\
\text { soles, extensor surfaces, } \\
\text { neck, perineum }\end{array}$ & $\begin{array}{l}\text { Primarily affects arms, } \\
\text { legs; less often seen } \\
\text { on trunk, face }\end{array}$ & $\begin{array}{l}\text { Annular or papulosquamous } \\
\text { eruption of shoulders, extensor } \\
\text { surfaces of arms, dorsal hands, } \\
\text { upper back, common on chest. } \\
\text { Telangiectasias }\end{array}$ \\
\hline Oral lesions & Rare & $25 \%-60 \%$ of cases & Rare & Rare \\
\hline Laboratory values & As per ARA criteria & $\begin{array}{l}\text { Mild elevation of ESR, } \\
\text { WBC }\end{array}$ & $\begin{array}{l}\text { Positive serum } \\
\text { rheumatoid } \\
\text { factor, speckled } \\
\text { ANA, precipitating } \\
\text { antibodies }\end{array}$ & $\begin{array}{l}\text { Positive ANA ( } 75 \%) \text {. } \\
\text { Positive SS-A/RO antibodies } \\
\text { via immunoassay } \\
(60 \%) . \\
\text { Positive RF }(30 \%-40 \%)\end{array}$ \\
\hline Histology & $\begin{array}{l}\text { Subepidermal vesicles } \\
\text { with neutrophils, nuclear } \\
\text { fragments, and fibrin at } \\
\text { tips of dermal papillae }\end{array}$ & $\begin{array}{l}\text { Early: Swelling of } \\
\text { endothelial } \\
\text { cells, superficial } \\
\text { perivascular mononuclear } \\
\text { infiltrate. } \\
\text { Late: Hydropic } \\
\text { degeneration, necrosis of } \\
\text { individual keratinocytes, } \\
\text { subepidermal } \\
\text { bullae }\end{array}$ & $\begin{array}{l}\text { Similar to EM; prominent } \\
\text { necrosis of keratinocytes }\end{array}$ & $\begin{array}{l}\text { Liquefaction of basal cell layer } \\
\text { perivascular, } \\
\text { periappendageal, } \\
\text { mononuclear cell } \\
\text { infiltrate in upper } \\
\text { third of dermis }\end{array}$ \\
\hline Immunology & $\begin{array}{l}\text { Linear IgA, IgG, IgM } \\
\text { and less frequently } \\
\text { C3 at basement sublamina } \\
\text { densa }\end{array}$ & $\begin{array}{l}\text { Early: Granular IgM, C3 in } \\
\text { capillary dermal } \\
\text { blood vessels. } \\
\text { Late: Granular C3 along } \\
\text { dermal-epidermal zone. } \\
\end{array}$ & Similar to EM & $\begin{array}{l}\text { Lesional; linear IgA, IgG, IgM, C3 } \\
\text { at d-e junction in } 60 \% \text { of } \\
\text { patients; nonlesional - } \\
35 \% \text { of patients }\end{array}$ \\
\hline Course/prognosis & $\begin{array}{l}\text { Often flares with } \\
\text { systemic disease activity; } \\
\text { responsive to dapsone }\end{array}$ & $\begin{array}{l}\text { Erupts over } 3-5 \text { years } \\
\text { days; heals in } 2 \\
\text { weeks. } 22 \%-37 \% \\
\text { recurrence rate }\end{array}$ & $\begin{array}{l}\text { Long Standing:Recurs } \\
\text { frequently over many } \\
\text { years }\end{array}$ & $\begin{array}{l}50 \% \text { may be classified as SLE } \\
\text { although systemic } \\
\text { disease is mild; is } \\
\text { photoexacerbated; } \\
\text { antimalarials, systemic } \\
\text { corticosteroids } \\
\text { useful }\end{array}$ \\
\hline
\end{tabular}

From Fitzgerald et al - Journal of the American Academy of Dermatology, Nov. 1996

Note: SLE - systemic lupus erythematosus; SCLE - subacute cutaneous lupus erythematosus; EM - erythema multiforme

but, the treatment improved the patient's quality of life, esthetic impact, diminished local pain and pruritus.

In our opinion, in spite of the controversial aspects regarding the existence of Rowell's syndrome $(3,6,8)$, this diagnosis should be consider in any pa- tient with these specific clinical features and immunological abnormalities. A good collaboration between rheumatologist, dermatologist and pathologist is necessary in order to establish proper diagnosis and treatment, thus improving the outcome and quality of life.

\section{REFERENCES}

1. Rowell NR, Beck S, Anderson JR. - Lupus erythematosus and erythema multiforme-like lesions. Arch Dermatol 1963; 88: $176 \pm 80$.

2. N.C. Zeitouni, D. Funaro, R.A. Cloutier, et al. - Redefining Rowell's syndrome; British Journal of Dermatology 2000; 142: 343 \pm 346 .

3. Antiga E., Caproni M., Bonciani D. et al. - The last word on the so-called 'Rowell's syndrome'? Lupus 2012; 21: 577-85.

4. Aydogan K., Karadogan S., Balaban Adim S. et al. - Lupus erythematosus associated with erythema multiforme: report of two cases and review of the literature. J Eur Acad Dermatol Venereol 2005; 19: 621-627.

5. Lee S., Schloss E., Kowichi J. - Rowell's syndrome: a case report with subacute cutaneous lupus erythematosus and erythema multiforme. Can J Dermatol 1995; 7:807 \pm 10 .

6. Modi G.M., Shen A., Mazloom A., et al. - Lupus erythematosus masquerading as erythema multiforme: does Rowell syndrome really exist? Dermatol Online J 2009; 15: 5.

7. Roustan G., Salas C., Barbadillo C. - Lupus erythematosus with an erythema multiforme-like eruption. Eur J Dermatol 2000; 10: 459-462.

8. Khandapur S., Suchibrata S., Singh M. - Rowell's syndrome revisited: reported of two cases from India. Int J Dermatol 2005; 44: 545-549

9. Marzano A.V., Lazzari R., Polloni I. et al. - Drug-induced subacute cutaneous lupus erythematosus: evidence for differences from its idiopathic counterpart. Br J Dermatol 2011; 165: 335-41. 
10. Hautmann G., Lotti T. - Psychoactive drugs and skin. J Eur Acad Dermatol Venereol 2003; 17: 383-293

11. Shteyngarts A.R., Warner M.R., Camisa C. - Lupus erythematosus associated with erythema multiforme: does Rowell's syndrome exist? J Am Acad Dermatol 1999; 40: 773-777.

12. Torchia D. - Rowell syndrome categorized as cutaneous lupus erythematosus subtype. J Am Acad Dermatol 2012; 67:417-21.

13. Gilliam J.N., Sontheimer R.D. - Distinctive cutaneous subsets in the spectrum of lupus erythematosus. J Am Acad Dermatol. 1981; 4:471-5;

14. Sontheimer R.D. - Skin manifestations of systemic autoimmune connective tissue disease: Diagnostics and therapeutics. Best Pract Res Clin Rheumatol. 2004;18:429-62.

15. Biazar C., Sigges J., Patsinakidis N. et al. - (2013) EUSCLE coauthors. Cutaneous lupus erythematosus: first multicenter database analysis of 1002 patients from the European Society of Cutaneous Lupus Erythematosus (EUSCLE). Autoimmun Rev 12: 444-454

16. Fitzgerald E.A., Purcell S.M., Kantoret G.R. et al - Rowell's syndrome: report of a case - Journal of the American Academy of Dermatology, Nov. 1996

17. Rothfield N., Sontheimer R.D., Bernstein M. - Lupus erythematosus: Systemic and cutaneous manifestations. Clin Dermatol. 2006;24:348-62

18. Müller C.S., Hinterberger L.R., Vogt T. - Successful treatment of Rowell syndrome using oral cyclosporine A. Int J Dermatol 2011; 50:1020-2. 